\title{
THE ABSORPTION OF ORALLY ADMINISTERED EMULSIFIED LIPID IN NORMAL CHILDREN AND IN CHILDREN WITH STEATORRHEA ${ }^{1,2}$
}

\author{
By CHARLES D. MAY 3 AND CHARLES UPTON LOWE 4 \\ WITH THE TECHNICAL ASSISTANCE OF ANITA SHENBERG \\ (From the Department of Pediatrics of the Harvard Medical School and the Infants' and \\ Children's Hospitals, Boston)
}

(Received for publication September 15, 1947)

\section{INTRODUCTION}

Vitamin $\mathrm{A}$ is a lipid whose identification in the peripheral blood is relatively simple. We have used this substance to study absorption of lipids from the intestine. The observation was made that oily preparations of vitamin A appeared to be less easily absorbed than a preparation intended to be mixed with ordinary infants' formulae (1). It occurred to us that this might be due to the vitamin $A$ being in an emulsified state when mixed with the formulae. The experiments herein reported were conducted with two purposes in mind : (1) to determine whether an orally administered emulsified lipid is absorbed better than an unemulsified lipid in individuals with impaired absorption of fat, and (2) to investigate the validity of the Frazer "Partition Hypothesis" for lipid absorption (2).

Frazer's "Partition Hypothesis" states that lipids may be absorbed from the gastrointestinal tract without lipolysis. His theoretical considerations are substantiated by feeding marked fats, by chylomicron counts on the peripheral and portal blood, and by direct observation of the intestine and lacteals of animals during acute experiments. Sinclair (3) has offered evidence in support of the Vezar theory of fat absorption (lipolysis and phosphorylation). Fats foreign to the normal animal organism have been identified following ingestion as part of the phospholipids of the intestinal mucosa. It would seem that both mecha-

\footnotetext{
1 This material was presented in part before the Society for Pediatric Research, May 13, 1947, at Stockbridge, Mass.

2 Aided by a grant from Mead Johnson and Company.

${ }^{8}$ Now Associate Professor, Department of Pediatrics, University of Minnesota.

- Blackfan Research Fellow in Pediatrics, Harvard Medical School.
}

misms of absorption of fat may occur. The quantitative contribution of each mechanism has not been ascertained.

\section{PLAN OF STUDY}

Vitamin A absorption curves were obtained in three groups of children using a procedure previously reported (4). The plasma vitamin A levels are reported in arbitrary galvanometer units $(\mathrm{L}-620 \cdot$ units per $100 \mathrm{cc}$. plasma). In all the experiments the test dose of vitamin A preparation was given after a 12-hour fast and followed by $300 \mathrm{cc}$. of whole cow's milk or a normal breakfast.

The first group was composed of 14 normal children convalescent from acute infections. The second group of absorption curves was obtained from 14 children with fibrosis of the pancreas in whom it had been demonstrated that tryptic activity was deficient in the duodenal secretions. Lipase is also deficient in these children because of the complete destruction of the exocrine portion of the pancreas. The third group of absorption curves was obtained from 6 children with steatorrhea due to the "celiac" type of disorder.

The materials used in the experiments are listed in Table I. Unemulsified vitamin A (I), largely in ester form, derived from fish liver oils was administered to these three groups of children. An emulsion composed of 15 per cent vitamin $A$ acetate, 15 per cent Tween $20^{5}$ and 70 per cent water (II) was prepared in which the oil droplet size varied from 0.5 to 10.0 microns; this too was administered to these three groups of patients. Also given to 3 normal children was a standard test dose of unemulsified vitamin A esters accompanied by 10 grams of pancreatin (III). Two normal children received $4 \mathrm{cc}$. of Tween 20 alone (IV).

To a group of 5 children with fibrosis of the pancreas, a test dose of unemulsified vitamin $\mathbf{A}$ esters were administered accompanied by 5 to 20 grams of commercial

5 The Tweens (Atlas Powder Co.) are a class of nonionic surface-active agents. The hydrophylic portion of the molecule is composed of free hydroxy groups and an oxyethylene chain. The lypophilic portion in the case of Tween 20 is lauric acid. The Tweens are excellent emulsifying agents and as far as is known these compounds are not toxic when fed to animals or humans. 
TABLE I

Materials used in experiments

I. Unemulsified vitamin A esters

(Mead Johnson and Company: Oleumpercomorphum)

II. Vitamin A acetate emulsion

(Prepared by Abbott Research Laboratories, Inc.)

III. Unemulsified vitamin A esters plus pancreatin

(Parke Davis and Co.: Enteric Granules)

IV. Polyoxethylene sorbitan monolaurate

(Atlas Powder Company: Tween 20)

V. Emulsified vitamin A esters

VI. Propylene glycol

(Glogau and Company, Chicago)

VII. Crystalline vitamin A alcohol

(Distillation Products, Inc., Rochester, N. Y.)

pancreatin (III) and absorption curves obtained. Finely emulsified vitamin A esters (V) were administered to 3 children with fibrosis of the pancreas. Preparation $\mathbf{V}$ contained propylene glycol, 6 and because some alcohols alone when administered by mouth are capable of producing a marked elevation in the plasma vitamin A (5), it was thought necessary to administer propylene glycol (VI) alone to exclude this phenomenon. This was performed on 5 normal controls.

6 Propylene glycol was used to enhance emulsification. Vitamin A esters are partially soluble in it, and. it in turn is completely miscible with water.
60,000 I.U. Vitamin A/gram 8,500 I.U. Vitamin D/gram

$15 \%$ Vitamin A acetate $15 \%$ Tween 20

$70 \%$ Water

3 times U.S.P. trypsin activity. Lipase activity not specified but similar preparations have been found to be very low in lipolytic activity (12)

$33 \%$ Oleumpercomorphum

$24 \%$ Tween 20

$38 \%$ Water

$5 \%$ Propylene glycol

\section{3,000 I.U. Vitamin A/milligram}

The size of the visible particles in all these emulsions was determined microscopically by dark field and light field examinations of the oily films with an ocular micrometer disk.

\section{RESULTS}

These are summarized in Table II.

\section{Normal children:}

Unemulsified vitamin $A$ in the form of oleumpercomorphum (I), when given to the normal

TABLE II

Summary of vitamin $A$ absorption experiments on normal patients, patients with fibrosis of the pancreas, and patients with steatorrhea*

\begin{tabular}{|c|c|c|c|c|c|c|c|c|c|c|}
\hline \multirow[b]{2}{*}{ Experimental material } & \multirow{2}{*}{$\begin{array}{l}\text { Average } \\
\text { particle } \\
\text { size in } \\
\text { microns }\end{array}$} & \multicolumn{3}{|c|}{ Normal patients } & \multicolumn{3}{|c|}{$\begin{array}{l}\text { Patients with fibrosis } \\
\text { of the pancreas }\end{array}$} & \multicolumn{3}{|c|}{ Patients with steatorrhea } \\
\hline & & $\begin{array}{c}\text { Aver. } \\
\text { max. } \\
\text { rise of } \\
\text { plasma } \\
\text { vit. A }\end{array}$ & $\begin{array}{c}\text { Range of } \\
\text { plasma } \\
\text { vit. A } \\
\text { rise }\end{array}$ & $\begin{array}{c}\text { No. of } \\
\text { patients } \\
\text { in } \\
\text { experi- } \\
\text { ment }\end{array}$ & $\begin{array}{c}\text { Aver. } \\
\text { max. } \\
\text { rise of } \\
\text { plasma } \\
\text { vit. A }\end{array}$ & $\begin{array}{c}\text { Range } \\
\text { of } \\
\text { plasma } \\
\text { vit. A } \\
\text { rise }\end{array}$ & $\begin{array}{c}\text { No. of } \\
\text { patients } \\
\text { in } \\
\text { experi- } \\
\text { ment }\end{array}$ & $\begin{array}{l}\text { Aver. } \\
\text { max. } \\
\text { rise of } \\
\text { plasma } \\
\text { vit. A }\end{array}$ & $\begin{array}{c}\text { Range } \\
\text { of } \\
\text { plasma } \\
\text { vit. A } \\
\text { rise }\end{array}$ & $\begin{array}{c}\text { No. of } \\
\text { patients } \\
\text { in } \\
\text { experi- } \\
\text { ment }\end{array}$ \\
\hline $\begin{array}{l}\text { I. Unemulsified vitamin A } \\
\text { esters } \\
\text { II. Vitamin A acetate } \\
\text { emulsion } \\
\text { III. Unemulsified vitamin A } \\
\text { esters plus pancreatin } \\
\text { IV. Polyoxyethylene } \\
\text { sorbitan monolaurate } \\
\text { V. Emulsified vitamin A } \\
\text { esters } \\
\text { VI. Propylene glycol } \\
\text { VII. Crystalline vitamin A } \\
\text { alcohol }\end{array}$ & $0.5-10$ & $\begin{array}{c}(119) \dagger \\
258 \\
232 \\
77 \\
1\end{array}$ & $\begin{array}{c}(52-283) \dagger \\
89-557 \\
47-305 \\
5-134 \\
0-1\end{array}$ & $\begin{array}{c}(47) \dagger \\
8 \\
9 \\
3 \\
2\end{array}$ & $\begin{array}{r}7 \\
119 \\
58\end{array}$ & $\begin{array}{c}0-15 \\
16-292 \\
36-94 \\
36-64 \\
94-114\end{array}$ & $\begin{array}{r}7 \\
11 \\
5\end{array}$ & $\begin{array}{l}40 \\
49\end{array}$ & $\begin{array}{c}6-88 \\
14-113\end{array}$ & $\begin{array}{l}6 \\
3\end{array}$ \\
\hline
\end{tabular}

* All values for vitamin A are expressed in $L-620$ units per $100 \mathrm{cc}$. of plasma.

† May (13). 
group of children, produced rises in the plasma vitamin $\mathrm{A}$ which were quite comparable to those which had been previously reported (6). Vitamin A acetate in Tween 20 (II), given to the same group of normal children, produced a similar though greater elevation in plasma vitamin A. As shown by the data in Table II, Tween 20 administered alone to 3 normal children produced no change in the plasma vitamin $\mathrm{A}$. The 3 normal children given vitamin A esters plus pancreatin (III) gave normal curves in two instances and a lowered curve in the third. The administration of propylene glycol (VI) alone to the normal group in amounts similar to those given with the emulsified vitamin A esters (V) produced no change in plasma vitamin $\mathrm{A}$.

\section{Fibrosis of the pancreas:}

Children in whom the diagnosis of fibrosis of the pancreas had been made were given unemulsified vitamin A esters in the form of oleumpercomorphum (I), and the maximum rise of plasma vitamin A was, as may be seen in Table II, extremely low. When vitamin $\mathrm{A}$ was given to this group as vitamin A acetate in Tween 20 (II) and as emulsified vitamin $A$ esters, a rise in plasma vitamin A occurred of about the extent observed in the normal controls. When unemulsified vitamin A esters were given with pancreatin (III) to patients with fibrosis of the pancreas, considerable increase in plasma vitamin A was noted, but the rises did not approach those obtained either in the normal group or in the same patients with the other emulsified forms of vitamin A.

The magnitude of response was not uniform in all the children with fibrosis of the pancreas. Two of the 11 patients given vitamin $A$ acetate in Tween 20 showed little rise in plasma vitamin A. All the patients given pancreatin plus vitamin A showed consistent responses.

\section{Steatorrhea:}

Children with steatorrhea were given vitamin A acetate emulsion (II), and the results as seen in Table II were quite comparable to those obtained with children who had fibrosis of the pancreas with the exception that the magnitude of elevation was slightly less.

\section{DISCUSSION}

The absorption curves in normal children serve only to demonstrate that normal individuals absorbed the tested materials well, and that neither propylene glycol nor Tween 20 was per se capable of eliciting an elevation in plasma vitamin A. Of much greater interest were the results obtained in children with fibrosis of the pancreas. All preparations of vitamin A which resulted in improved absorption were found in vitro to be made up of droplets 0.5 to 10 microns in diameter and may be assumed to have presented this lipid to the intestine in a fine particulate state. According to Frazer's hypothesis, this would account for the improved absorption in the absence of lipase. Indeed these experiments may be considered to offer further evidence in support of Frazer's hypothesis. It would be difficult to explain these results by the classical lipolysis theory of fat absorption.

Vitamin A in its crystalline form is an alcohol. In fish liver oils it is largely esterified with high molecular weight fatty acids. As an ester its digestion has been thought to follow the route of other esters, such as neutral fats, and thus to be dependent upon lipolysis. ${ }^{7}$ Adlersberg and Sabotka (7) found that when vitamin A was administered with phosphatids to adults with steatorrhea, the amount of vitamin A absorbed per unit time was increased. Although they felt that the enhanced absorption was due to increased emulsification, they reasoned that one could not be sure that the increased emulsification did anything more than permit more rapid lipolysis. This explanation would seem to be invalid in children with fibrosis of the pancreas because they have no pancreatic lipase, although the possibility remains that traces of lipolytic activity may be present in the intestine derived from sources other than the pancreas. Possibly creation of an emulsion with particles of the appropriate size ( 0.5 micron) enables the gastrointestinal tract to absorb oily material independent of lipolytic digestion.

7 Crystalline vitamin A alcohol (VII) was administered to 2 children with fibrosis of the pancreas in a dose of 6,000 I.U. per $1 \mathrm{~b}$. This was given mixed with applesauce. It is seen in Table II that normal absorption curves were obtained. Good absorption of crystalline vitamin $A$ alcohol by children with fibrosis of the pancreas has also been reported by Clausen (9). 
The explanation for the few instances of poor absorption in children with fibrosis of the pancreas or steatorrhea when given finely emulsified vitamin A remains obscure. It is possible that intestinal hypomotility could account for this. The poor absorption of dextrose in such patients has been found to be due in part to intestinal hypomotility (8).

The observation that the addition of pancreatin to unemulsified vitamin A produced considerable increase in its absorption by children lacking lipase also requires explanation. This observation has been previously made by Clausen (9). When Frazer (10) fed rats triglycerides marked with Sudan IV, he observed staining of the fat depots and a postprandial elevation of lipid in the systemic circulation. When this same material was fed with lipase, he noted neither systemic lipemia nor staining of the fat depots. Rather he observed a portal lipemia and staining of the liver sinusoids. When adult humans were fed triglycerides (11), he observed again a systemic lipemia, but administration of lipase with equal amounts of fat abolished this phenomenon. Frazer interpretated these observations to indicate that addition of lipase augmented hydrolysis and subsequent absorption by the portal route. It would seem that pancreatin, which is poor in lipase (12), when administered to the children with absent lipase, must act mainly as an emulsifying agent.

If the increased absorption of emulsified vitamin A indicates enhanced lipid absorption, the implications would seem significant. A principal difficulty in maintaining children with chronic intestinal insufficiency is to supply them with sufficient calories in a form easily available at a period when most needed. If one could administer fat in a form that could be absorbed independent of low lipase, intestinal hypomotility, or other causes of malabsorption, it is possible that considerable progress might be made in aiding the nutrition of these children. Finally, it is possible that the oral administration of emulsified lipids to children recuperating from diarrhea might be of benefit. Studies are now in progress on the effect of feeding emulsified fats to these types of children and determining the absorption of the fats by balance measurements.
SUM MARY

The oral administration of emulsified vitamin A to normal children produced an elevation of plasma vitamin A comparable to that obtained when unemulsified vitamin $\mathrm{A}$ was administered. When these same emulsified preparations were given to children with steatorrhea, whether due to absent lipase or to other causes, there resulted a considerable improvement of absorption of vitamin A to approximately normal. Administration of unemulsified vitamin A resulted in poor absorption. The addition of commercial pancreatin to unemulsified vitamin A produced considerable increase in absorption in children lacking pancreatic secretions, but of less extent than was gained by giving emulsified vitamin A. These results suggest an enhanced absorption of food lipids by children with steatorrhea when provided in emulsified form.

\section{ACKNOWLEDGMENT}

We are indebted to Dr. A. E. Osterberg of Abbott Research Laboratories, Inc., for the preparation and generous supply of emulsions of vitamin A acetate with Tween 20.

\section{ADDENDUM}

Since this report was presented, Kramer et al. ${ }^{8}$ have reported enhanced absorption of vitamin A esters, when mixed with wetting agents, in 5 patients with "celiac disease," and Lewis et al..$^{9}$ in an excellent study of absorption of "aqueous preparations" of vitamin A reported enhanced absorption in one child with fibrosis of the pancreas.

\section{BIBLIOGRAPHY}

1. Clifford, S. H., The absorption of vitamin $\mathrm{A}$ by the premature infant. Read by title before the Society for Pediatric Research, May 1, 1946.

2. Frazer, A. C., Absorption of triglyceride fat from the intestine. Physiol. Rev., 1946, 26, 103.

3. Sinclair, R. G., and Smith, C., The turnover of phospholipids in the intestinal mucosa. J. Biol. Chem., 1937, 121, 361.

4. May, C. D., and McCreary, J. F., The absorption of vitamin A in celiac disease; interpretation of vita-

8 Kramer, B., Sobel, A. E., and Gottfried, S. P., Serum levels of vitamin $\mathrm{A}$ in children. Am. J. Dis. Child., 1947, 73, 543.

9 Lewis, J. M., Bodansky, O., Birmingham, J., and Cohlan, S. Q., Comparative absorption, excretion, and storage of oily and aqueous vitamin A. J. Pediat., 1947, $31,496$. 
min A absorption test. J. Pediat., 1941, 18, 200209.

5. Clausen, S. W., Baum, W. S., McCoord, A. B., Rydeen, J. O., and Breese, B. B., The mobilization by alcohols of vitamin $A$ from its stores in the tissues. J. Nutrition, 1942, 24, 1.

6. May, C. D., Blackfan, K. D., McCreary, J. F., and Allen, F. H., Jr., Clinical studies of vitamin A in infants and children. Am. J. Dis. Child., 1940, $59,1167$.

7. Adlersberg, D., and Sabotka, H., Influence of lecithin feeding on fat and vitamin $A$ absorption in man. J. Nutrition, 1943, 25, 255.
8. May, C. D., and McCreary, J. F., The glucose tolerance test in celiac disease; significance of low blood sugar curves. J. Pediat., 1940, 17, 143.

9. Clausen, S. W., The absorption of vitamin A and its storage in the tissues. The Harvey Lectures, 1942-1943, 38, 199.

10. Frazer, A. C., Differentiation in the absorption of olive oil and oleic acid in the rat. J. Physiol., 1943, 102, 306.

11. Frazer, A. C., Lipolysis and fat absorption. J. Physiol., 1943, 102, 329.

12. Shwachman, H., Personal communication.

13. May, C. D., Unpublished data. 